\title{
Effect of Signature Card on Disposition of Joint Bank Account upon Death of Co-Owner under New York Banking Law
}

\author{
James B. Biagi \\ School of Business and Global Innovation, Marywood University, Scranton, PA, USA \\ Email: Biagi@marywood.edu
}

Received 3 September 2014; revised 1 October 2014; accepted 28 October 2014

Copyright (C) 2014 by author and Scientific Research Publishing Inc.

This work is licensed under the Creative Commons Attribution International License (CC BY). http://creativecommons.org/licenses/by/4.0/

\section{(c) (i) Open Access}

\begin{abstract}
It is a common practice for people to open a bank account in the name of one or more owners (a/k/a co-owners) and not just in the name of a single person alone. It is also common for an individual to be added to the ownership of an existing account once it has been established. Oftentimes spouses, friends, family or business associates decide for various reasons, both financial and personal, to establish a joint bank account and hold it as co-owners. Furthermore, as the population ages, it has become a common practice for elderly individuals to place another person's name on a bank account, effectively creating a joint account arrangement for a once individually held account. As is often the case when multiple parties share in a financial transaction, disputes can arise as to the disposition of the funds held in such an account, either during life or at death. In order to address this issue, New York, a major world financial center, has put in place specific legislation to address the disposition of a joint bank account governed by the laws of that State. In this article, the author discusses New York Banking Law $\$ 675$ and its application to the transfer of funds held in a joint account at the death of a co-owner, paying particular attention to the effect of the account's signature card on the issue.
\end{abstract}

\section{Keywords}

Joint Bank Account, Signature Card, Joint Tenants with Rights of Survivorship, Tenants in Common

\section{Introduction}

New York Banking Law ("BL”) §675 provides that when a deposit has been made with a banking organization transacting business in New York in the name of a depositor and another person and in a form to be paid or de- 
livered to either, or the survivor of them, such deposit shall become the property of such persons as joint tenants and may be paid to the survivor(s) at the death of one of them. This simple principle applies to the disposition of the account proceeds at death irrespective of the contributions made to it by each co-owner. When creating a joint account arrangement, each co-owner may contribute equal or unequal amounts and in some cases, nothing at all. Despite the level of contribution made by each co-owner, the account becomes the property of the survivor(s) upon the death of one of them if this rule applies. BL $\S 675$ creates requirements for the imposition of this principle, and New York law also addresses the disposition of the funds in a joint bank account if this rule is inapplicable.

\section{The Elements of Banking Law $\$ 675$}

The rules governing the disposition of a bank account vary from state to state. With regard to bank accounts established under New York law, BL §675(a) provides the following, in pertinent part:

"When a deposit of cash...has been made... with any banking organization...transacting business in this state...in the name of the depositor... and another person and in form to be paid or delivered to either, or the survivor of them, such deposit... and any additions thereto made, by either of such persons...shall become the property of such persons, as joint tenants... and may be paid or delivered to either during the lifetime of both or to the survivor after the death of one of them...”.

BL §675(b) further provides that:

"The making of such deposit...shall, in the absence of fraud or undue influence, be prima facie evidence, in any action or proceeding to which the...surviving depositor...is a party, of the intention of both depositors ...to create a joint tenancy and to vest title to such deposit... and additions...in such survivor.”

Therefore, when an account has been formed in accordance with this statute, ownership of the account vests in the surviving co-owner(s) upon the death of one of them. The New York Banking Law achieves this result by creating a presumption that, in the absence of fraud or undue influence, the parties intended to create a joint tenancy, vesting title in the survivor upon the death of one of the account holders. This concept is referred to as "survivorship” or “rights of survivorship” (Matter of Stalter, 2000; Estate of Corcoran, 2009; Matter of Camarda, 1978; Jacks v. D’Ambrosio, 2010). The above-referenced presumption exists irrespective of the contribution made to the account by each co-owner and may be inconsistent with the deceased co-owner's other estate planning documents.

The surviving co-owner(s), therefore, is entitled to the account proceeds unless the heirs of the deceased can rebut the presumption of joint tenancy or show fraud or undue influence; a burden that is often difficult to meet. Because of the significance of the presumption and its effect on the disposition of the account proceeds, a question arises as to what documentation, if any, is needed to establish this presumption of survivorship. When applying this statute, the New York Courts have looked for a clear statement of the parties' intent to create this right of survivorship.

The Courts have often looked to the account's signature card for a demonstration of this intent. The Courts have consistently held that this presumption may not apply if the signature card for the account fails to contain language indicating a right of survivorship or is lost or unavailable.

\section{Importance of Account Signature Card}

As previously noted, the New York Courts have generally held that the signature card for an account must contain words indicating the intent to create a right of survivorship, such as "payable to either or the survivor", or similar verbiage. Language to this effect must appear on the signature card in order to take advantage of the statutory presumption that title of the account passes to the remaining co-owner(s) on the death of one of them (Matter of Stalter, 2000; Matter of Klecar, 1994; Matter of Tomoshevich, 1987).

If this survivorship language is present on the signature card, the burden of proof shifts to the party challenging that the account title vests in the surviving co-owners to rebut the presumption of survivorship. See BL §675(b). This challenging party must establish by clear and convincing evidence that the account should not be treated as a survivorship account payable to remaining co-owners (Matter of Camarda, 1978; Jacks v. D’Ambrosio, 2010; Warren v. Warren, 1983; McGill v. Booth, 1983). If the challenging party can’t meet this difficult 
burden, the account passes to the surviving co-owners. Aside from allegations of fraud or undue influence, the most common challenge to this presumption of survivorship can be found in evidence that the account was established for the convenience of the deceased co-owner and not with the intent to confer a present interest in the survivor(s) (Matter of Mantione, 2009; Matter of Friedman, 1984). If the evidence proves the existence of a convenience account, the proceeds in question actually pass under the terms of the decedent's estate plan and not through survivorship.

If the signature card fails to bear specific language as to survivorship or is lost, the statutory presumption in favor of joint tenancy with rights of survivorship does not apply. More importantly, in the absence of this statutory presumption, the burden remains on the surviving account holder to establish that the decedent intended to create a joint tenancy with rights of survivorship by clear and convincing evidence (BL §675(b); Estate of Corcoran, 2009). Therefore, the presumption of title vesting in the survivor under BL $\S 675$ does not apply where the signature card for the account fails to contain the words "payable to either or the survivor", or similar survivorship language, or is unavailable (Matter of Stalter, 2000; Matter of Klecar, 1994; Matter of Coon, 1989; Matter of Timoshevich, 1987; Matter of Camarda, 1978; Lombardi v. First National Bank of Hancock, 1965).

Without this presumption in favor of the surviving co-owners, it is often difficult to show the existence of the right of survivorship. Even if the surviving co-owners are not afforded the benefit of the statutory presumption of co-ownership under BL §675, other evidence may establish the existence of a survivorship account. This evidence can include bank regulations, employee testimony and the like. In Matter of Butta (2004), the Court relied on the testimony of a bank employee to establish the content of a destroyed signature card to establish the right of survivorship.

If the evidence doesn't establish the existence of a survivorship account, New York laws creates a further statutory presumption under Estate Powers and Trust Law (“EPTL”) §6-2.2(a) that assets owned as joint tenants are held in common and not with rights of survivorship, unless a contrary rule applies. If a surviving co-owner is without a proper signature card and evidence of survivorship, the deceased co-owner's interest in a bank account (assumedly one-half) would pass under his/her estate plan while the remaining portion would remain titled to the survivor(s). Therefore, if BL §675(a) is inapplicable to an account, the statutory presumption of EPTL §6-2.2(a) that the disposition of property to two or more people creates in them a tenancy in common is applicable (Estate of Randall, 1991).

\section{Conclusion}

People often establish a bank account in multiple names without considering the ramifications, especially the effect on the distribution of the account at death. New York Bank Law $§ 675$ has been established to address this situation. It creates a presumption that the parties in this situation intend to pass the account proceeds to the other co-owners at death. This presumption exists only if the documents establishing the account, in particular the signature card, express the intent of the parties to do so. In the absence of clear proof of this intent, the right of survivorship does not exist.

\section{References}

Estate of Corcoran, 63 A.D.3d 93 (3rd Dept. 2009).

Estate of Randall, 176 A.D.2d 1219 (4 $4^{\text {th }}$ Dept. 1991).

Jacks v. D’Ambrosio, 69 A.D.3d 574 (2nd Dept. 2010).

Lombardi v. First National Bank of Hancock, 23 A.D.2d 713 (3rd Dept. 1965).

Matter of Butta, 3 A.D.3d 347 (2nd Dept. 2004).

Matter of Camarda, 63 A.D.2d 837 (4th Dept. 1978).

Matter of Coon, 148 A.D.2d 906 (3rd Dept. 1989).

Matter of Friedman, 104 A.D.2d 366 (2nd Dept. 1984).

Matter of Klecar, 207 A.D.2d 732 (1st Dept. 1994).

Matter of Mantione, 66 A.D.3d 1468 (4th Dept. 2009).

Matter of Stalter, 270 A.D.2d 594 (3rd Dept. 2000).

Matter of Timoshevich, 133 A.D.2d 1011 (3rd Dept. 1987). 
McGill v. Booth, 94 A.D.2d 928 (3rd Dept. 1983).

New York Banking Law §675.

New York Estate Powers and Trust Law §6-2.2.

Warren v. Warren, 95 A.D.2d 807 (2nd Dept. 1983). 
Scientific Research Publishing (SCIRP) is one of the largest Open Access journal publishers. It is currently publishing more than 200 open access, online, peer-reviewed journals covering a wide range of academic disciplines. SCIRP serves the worldwide academic communities and contributes to the progress and application of science with its publication.

Other selected journals from SCIRP are listed as below. Submit your manuscript to us via either submit@scirp.org or Online Submission Portal.
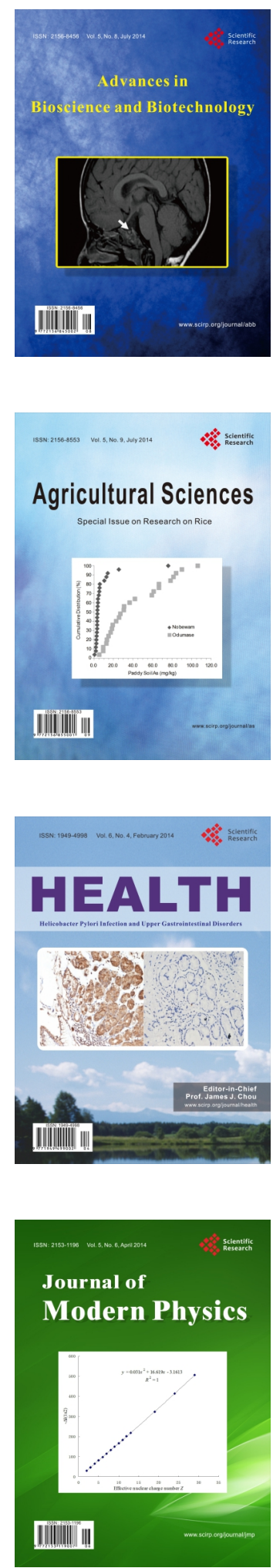
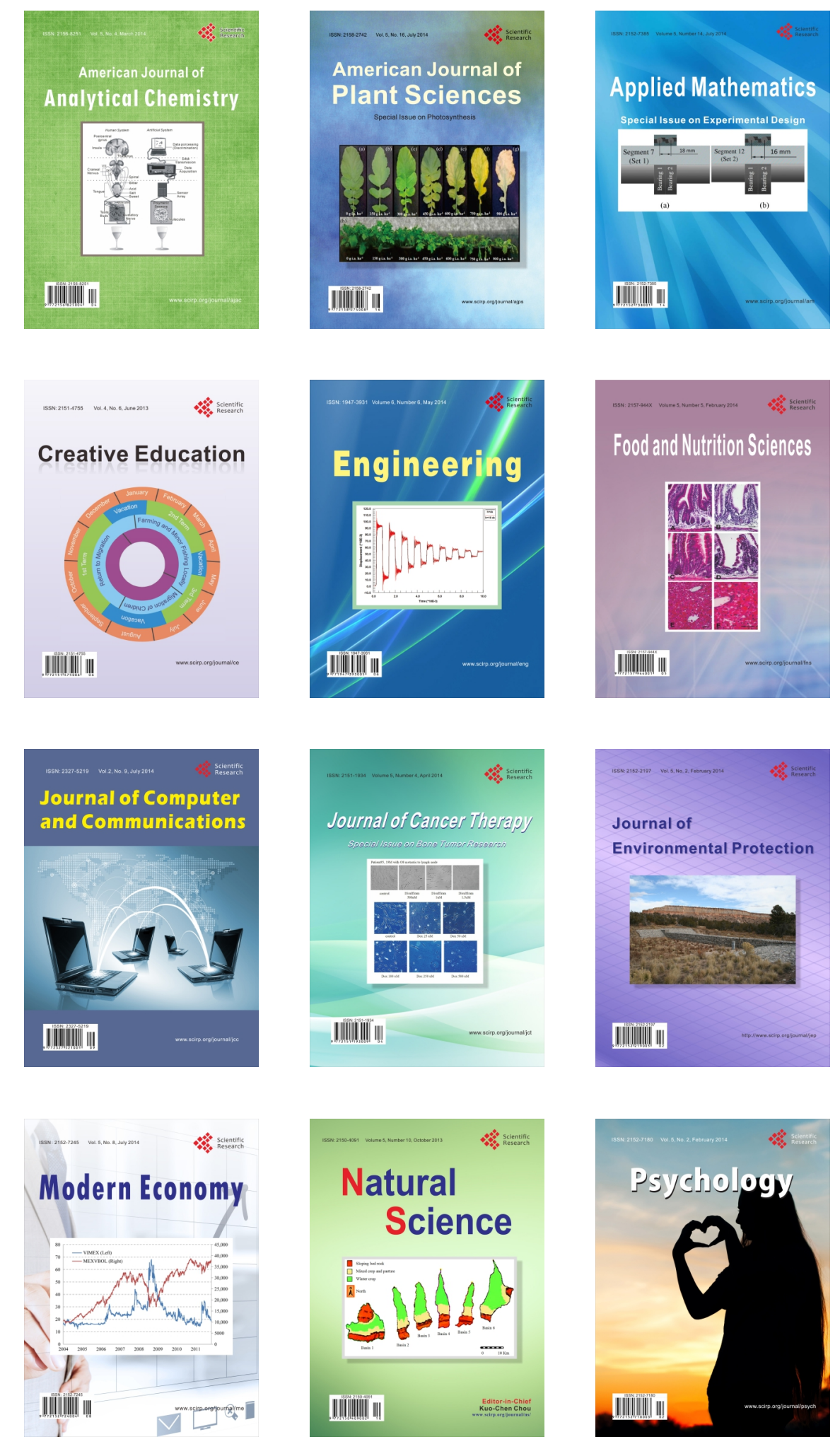